\title{
Cyanobacterium Spirulina platensis LUQS1: Effects on serum lipids and kidney in domestic cats, Felis catus
}

\author{
Lokman Shamsudin', Syarifah Ab Rashid ${ }^{1 *}$, Nur Nabila Mohd Rozaini² and Than Kyaw² \\ ${ }^{1}$ Institute of Food Security and Sustainable Agriculture (IFSSA), Universiti Malaysia Kelantan, Locked Bag No 100, \\ 17600 Jeli, Kelantan, Malaysia. \\ ${ }^{2}$ Faculty of Veterinary Medicine, Universiti Malaysia Kelantan, Jalan Padang Tembak, Kawasan Perindustrian Mara, \\ 16100 Kota Bharu, Kelantan, Malaysia \\ Email: than@umk.edu.my
}

Received 29 March 2017; Received in revised form 25 September 2017; Accepted 11 November 2017

\begin{abstract}
Aims: Researchers found a wide range of therapeutic properties in Spirulina sp. including as anti-cholesterol or antihyperlipidemic agent. In this study, the lipid levels of domestic $F$. catus were induced in order to scrutinize the antihyperlipidemic effects of local S. platensis LUQS1 strain, specifically at concentrations of $0.5 \mathrm{~g} / \mathrm{day}$ and $1.0 \mathrm{~g} / \mathrm{day}$.

Methodology and results: Elevation of serum lipid levels viz. total cholesterol (TC), high density lipoprotein (HDL), low density lipoprotein (LDL) and triglycerides (TG) as well as the status of kidney [creatinine (Cr) and blood urea nitrogen (BUN)] were observed in four groups of $F$. catus for 45 days. The highest levels for $T C$, $L D L$ and $T G(P<0.05)$ were recorded in high cholesterol diet group $(C D)$ at day 45 with $291.67 \pm 2.87 \mathrm{mg} \cdot \mathrm{dL}^{-1}, 111.60 \pm 9.73 \mathrm{mg} \cdot \mathrm{dL}^{-1}$ and $146.33 \pm 10.44 \mathrm{mg} \cdot \mathrm{dL}^{-1}$, respectively. HDL levels in Spirulina-treated groups (CA and CAA) were better than normolipidemic group (control, SD group), of which the maximum levels were displayed at day 30 specifically $72.87 \pm 6.08 \mathrm{mg} \cdot \mathrm{dL}^{-1}$ by cats-fed with high cholesterol diet treated with $0.5 \mathrm{~g} /$ day $S$. platensis LUQS1 (CA group). There were insignificant differences $(P>0.05)$ in the BUN levels; however, the Cr levels in CAA group (day 30 and 45 ) were slightly out of normal range but did not classify under chronic condition.

Conclusion, significance and impact of the study: Alternative treatments on hyperlipidemic cats were rarely reported by researchers and medicinal practitioners. Thus, the findings of this present study provided a genuine knowledge concerning the lipid-lowering effect of $S$. platensis LUQS1 on the hyperlipidemic cats.
\end{abstract}

Keywords: Spirulina sp., serum lipids, creatinine, blood urea nitrogen, cat

\section{INTRODUCTION}

Awareness on hyperlipidemia, obesity and hypertension in human are greatly given by researchers around the world. Indeed, they have overlooked a few of isolated reports on animals owing to the fact that it is infrequent for animals to develop heart disease related to hyperlipidemia or hypolipidemia like human. As a matter of fact, animals are commonly linked to serious or even fatal ailments such as obesity, vision, pancreatitis and neurologic problems (Kline, 2005; Remillard, 2005; Steiner and Williams, 2005; Tucci-Prosěk, 2005).

Spirulina sp. is formerly huddled under blue-green algae, however, due to its prokaryotic structure, it now belongs to cyanobacteria. It is enriched with proteins and vital nutrients, of which 18 essential amino acids (out of 22) are available within Spirulina. This cyanobacterium is also completed with $\beta$-carotene, making it a perfect antioxidant (El-Sabagh et al., 2014), anti-inflammatory (Muhammad Nazrul et al., 2014), anti-cholesterol (Kim and Kim, 2005), anti-pyretic (Muhammad Nazrul et al., 2014), antibacterial (Ozdemir et al., 2004) and also anticancer (Konícková et al., 2014) agent.

The first clinical trial of Spirulina sp. as an antihyperlipidemic agent was done on albino rats (Devi and Venkataranam, 1983). Since then, bigger models have constructively been used for lipid-related studies including on human (Nakaya et al., 1988), rabbits (Colla et al., 2008; Cheong et al., 2010) and pigs (Saeid et al., 2013). Information on cats is restricted due to their resistance capabilities towards cardiovascular diseases (CVDs) mostly atherosclerosis (Xiangdong et al., 2011). Cats are among animals with a null or low level of plasma cholesteryl ester transfer protein (CETP) and have naturally higher HDL particles in their bodies (GuyardDangremont et al., 1998). Nonetheless, cats are the great 
choice for primary and secondary hyperlipidemic disorders study (Kenneth, 2011). These animals have been accounted for several manifestations of lipid-related disorders such as diabetes mellitus, idiopathic hyperlipidemia, pancreatitis, nephrotic disorder, cholesterol ester stockpiling malady (Mosallanejad et al., 2016) and lipid aqueous (Kluger et al., 2009; Xenoulis and Steiner, 2010). To date, no single animal models could utterly represent human atherosclerosis; albeit, there are two common cats' features that relate to human, particularly the mechanical endothelial injury and cholesterol feeding behaviour (Xiangdong et al., 2011).

A potential role of Spirulina sp. in lowering the cholesterol levels either in animal or human is totally lacking and remains unclear. Generally, Spirulina sp. will bind with cholesterol metabolites bile acids in the liver and later, reduce the cholesterol solubility (Deng and Chow, 2010). In this investigation, priority was given to the beneficial effect of $S$. platensis LUQS1 with highlights on hyperlipidemic $F$. catus and the profile of $\mathrm{Cr}$ and BUN in signifying the cats' kidney status.

\section{MATERIALS AND METHODS}

\section{Source of S. platensis and maintenance}

The strain of $S$. platensis LUQS1 was isolated in Tasik Dayang Bunting, Langkawi, Kedah, Malaysia and maintained in modified Zarrouk medium (Zarrouk, 1966) at ambient temperature of $30 \pm 2{ }^{\circ} \mathrm{C}$, alkaline $\mathrm{pH}$ (8.5 to 9.0) and under cool white fluorescent source $(30 \mu \mathrm{mol}$ photon $\mathrm{m}^{-2} \mathrm{~s}^{-2}$.

\section{Animals, cholesterol and Spirulina diets}

Twelve healthy male of $F$. catus cats (size range: 2800$3161 \mathrm{~g})$ were assigned into four experimental groups; standard commercial diet (SD), high cholesterol diet (CD), cholesterol with $0.5 \mathrm{~g} /$ day $S$. platensis LUQS1 diet (CA) and cholesterol with $1.0 \mathrm{~g} /$ day $S$. platensis LUQS1 diet (CAA). A total of $9 \%$ cholesterol per body weight was added into the daily diet of CD, CA and CAA groups. The cholesterol preparation was done by adding the chloroform and dried in a fume hood, prior to mixing process in $100 \mathrm{~g}$ intact pellet. These 3 groups were fed with high cholesterol diet for 2 weeks and after that continued with normal commercial diet. The total treatment duration was 45 days and free water access ad libitum was provided throughout the experimental period. Concentrated $S$. platensis LUQS1 was given to the cats daily via oral-gavage procedure.

\section{Protein and lipid composition in animal Feed}

Protein and lipid contents were determined accordingly to the method of AOAC (1997).

\section{Biochemical analysis}

One millilitre $(\mathrm{mL})$ of blood was drawn from a cephalic vein using a needle with the size of $23 \mathrm{G}$ (Terumo, Japan). Blood was collected at day 0 (pre-treatment), 15, 30 and 45 (post-treatment). Samples were centrifuged at $5000 \mathrm{rpm}$ for $10 \mathrm{~min}$, prior to serum lipids evaluation (TC, LDL, TG and HDL) plus basic test of kidney-function ( $\mathrm{Cr}$ and BUN). All samples were analyzed via automatic analyzer Roche Cobas Mira (Thermo Fisher Scientific, United State of America) and Hitachi 902 Machine (Hitachi, Japan).

\section{Statistical analysis}

Statistical differences between treatment and control groups were analyzed via ANOVA SPSS version 22 (SPSS Statistics, IBM Corporation) and significance was accepted at $P<0.05$. All data were expressed as mean \pm standard deviation and levels of significance were represented by superscript alphabet.

\section{Animal ethics}

The guidelines on handling the experimental animals were in compliance with the standard operational procedure of animal ethics which were verified by Animal Ethics Committee (Faculty of Veterinary Medicine) in Universiti Malaysia Kelantan.

\section{RESULTS AND DISCUSSION}

\section{Growth performance}

Table 1.0 presents the diet compositions for all investigated groups and Table 2.0 displays the body weight differences for $F$. catus throughout 45 experimental days. According to the results of the final weights, it can be concluded that all diets managed to increase the cats' body weights. Yet, the highest daily weight gain $(P<0.05)$ was recorded by CAA group $(14.60 \pm 0.22 \mathrm{~g} /$ day) followed by CA $(9.98 \pm 0.84 \mathrm{~g} / \mathrm{day})$, SD $(9.78 \pm 1.20 \mathrm{~g} / \mathrm{day})$ and CD $(5.77 \pm 0.45 \mathrm{~g} /$ day) group. The total protein $(33.10 \pm 0.07 \%)$ and lipid $(4.20 \pm 0.05 \%)$ contents in CAA group diet have significantly assisted the cats in increasing their body weights. Besides, the $S$. platensis LUQS1 supplementation which is generally known for its high protein, lipid and carbohydrate, has also contributed to the weight gain. As observed, the daily weight gain in CAA group ( $1.0 \mathrm{~g} / \mathrm{day})$ group has denoted $46 \%$ higher than the CA group ( $0.5 \mathrm{~g} /$ day). Comparing to the standard diet or normal group (SD), the CAA group increased to about $49 \%$ while the CD group stated a $41 \%$ reduction. Only the CD group demonstrated lower daily weight gain compared to others (CA and CAA groups) despite being supplied with the same cholesterol percentage ( $9 \%$ per body weight) in the diets. The daily weight gain between SD and CA groups displayed insignificant difference albeit their diet compositions (protein and lipid) were significantly different. 
Protein, carbohydrate and fat notoriously contribute in weight gaining either in human or animal. These elements consist of the distinguishable value of calories, approximately 4 calories per gram deposited by protein and carbohydrate and about 9 calories per gram by fat.

Table 1.0: The proximate composition of the experimental diets.

\begin{tabular}{lllll}
\hline $\begin{array}{l}\text { Compositions } \\
(\%)\end{array}$ & SD & CD & CA & CAA \\
\hline Crude protein & $19.80 \pm$ & $21.07 \pm$ & $26.53 \pm$ & $33.10 \pm$ \\
& $0.07^{\mathrm{a}}$ & $0.04^{\mathrm{ab}}$ & $3.55^{\mathrm{c}}$ & $0.07^{\mathrm{c}}$ \\
Crude lipid & $3.75 \pm$ & $4.12 \pm$ & $4.18 \pm$ & $4.20 \pm$ \\
& $0.10^{\mathrm{a}}$ & $0.06^{\mathrm{b}}$ & $0.03^{\mathrm{b}}$ & $0.05^{\mathrm{b}}$ \\
\hline
\end{tabular}

*SD: standard commercial diet group; CD: cholesterol diet group; CA: cholesterol with $S$. platensis LUQS1 (0.5 g/day) diet group; CAA: cholesterol with $S$. platensis LUQS1 (1 g/day) diet group; Values (mean \pm standard deviation) with different superscripts in the same row were significantly different at the $5 \%$ level

Table 2.0: Initial and final weight of animals during the treatment.

\begin{tabular}{clll}
\hline $\begin{array}{l}\text { Treatment } \\
\text { group }\end{array}$ & Initial weight $(\mathrm{g})$ & Final weight $(\mathrm{g})$ & $\begin{array}{l}\text { Daily weight } \\
\text { gain }(\mathrm{g} / \mathrm{day})\end{array}$ \\
\hline SD & $2870.67 \pm 47.11$ & $3310.67 \pm 7.11$ & $9.78 \pm 1.20^{\mathrm{b}}$ \\
CD & $2988.33 \pm 5.56$ & $3248.00 \pm 26.00$ & $5.77 \pm 0.45^{\mathrm{a}}$ \\
CA & $3139.33 \pm 14.44$ & $3588.33 \pm 23.56$ & $9.98 \pm 0.84^{\mathrm{b}}$ \\
CAA & $2967.00 \pm 4.67$ & $3624.00 \pm 11.33$ & $14.60 \pm 0.22^{\mathrm{c}}$ \\
\hline
\end{tabular}

${ }^{*}$ Values (mean \pm SD) with different superscripts in the same column were significantly different at the $5 \%$ level.

The supplementation of $S$. platensis LUQS1 resulted in a greater live weight and also daily weight gain of F.catus. These outcomes were in agreement with Nagaoka et al (2005), Colla et al. (2008), Heidarpour et al. (2011) and El-Sabagh et al. (2014) who have tested the effects of Spirulina sp. on rats, rabbits, calves and lambs, respectively. A complete set of nutrients in Spirulina sp. such as amino acids, vitamins, essential fatty acid, minerals and other nutrients, has possibly stimulated the gut microflora to exude extracellular enzymes that indirectly induced the growth of animals (Tovar-Ramírez et al., 2002; Gershwin and Belay, 2008). It is also worth to mention a report by Azabji-Kenfack et al. (2011) that the supplementation of $S$. platensis towards a group of emaciated HIV-infected adults in Africa has successfully gained $4.8 \mathrm{~kg}$ of their average weight. In human, essential amino acids are pivotal for anabolism and muscle mass reconstitution. According to Deng and Swanson (2015), the gut of canine and feline are similar to human's gut especially their faecal microbial phylogeny and functional capacity. These similarities include the functional groups related to protein, metabolism of vitamins, carbohydrate, DNA and other major capacities.

\section{Status of kidney}

The nitrogenous end products of metabolism in human and animal are urea and creatinine. Thus far both elements are the most appropriate markers for renal (kidney) damage detection. Table 3.0 denotes the average levels of BUN and $\mathrm{Cr}$ in $F$. catus throughout the study period. The normal ranges of BUN and $\mathrm{Cr}$ levels obtained from the SD group were $44.33-65.33 \mathrm{mg} \cdot \mathrm{dL}^{-1}$ and $1.60-1.83 \mathrm{mg} \cdot \mathrm{dL}^{-1}$, respectively. By referring to the BUN, all levels in the tested groups were within the normal ranges. As for $\mathrm{Cr}$, at day 30 and 45, the levels in CAA group were slightly out of normal ranges albeit not categorized under chronic condition. The $\mathrm{Cr}$ levels for both days were $1.93 \pm 0.11 \mathrm{mg} \cdot \mathrm{dL}^{-1}$ (day 30 ) and $2.13 \pm 0.04$ $\mathrm{mg} \cdot \mathrm{dL}^{-1}$ (day 45).

A normal cat has about $0.2-0.5 \mathrm{~g} \cdot \mathrm{L}^{-1}\left(20-50 \mathrm{mg} \cdot \mathrm{dL}^{-1}\right)$ serum urea and 6-19 $\mathrm{mg} \cdot \mathrm{L}^{-1}\left(0.6-1.9 \mathrm{mg} \cdot \mathrm{dL}^{-1}\right)$ serum $\mathrm{Cr}$ (Chetboul et al. 2003). According to our recent results, only the serum $\mathrm{Cr}$ was in agreement with the aforementioned outcomes. Deguchi and Akuzawa (1997) have reported that the average levels of BUN and $\mathrm{Cr}$ in cats with chronic renal damage were $136.7 \mathrm{mg} / 100 \mathrm{~mL}$ and $5.09 \mathrm{mg} / 100 \mathrm{~mL}$, respectively. To obtain a more precise result, it is recommended to measure the quantity of glomerular filtration, the quantity of urine excreted and also the tubular re-absorption rate (Deguchi and Akuzawa, 1997).

\section{Serum lipids of $\boldsymbol{F}$. catus}

Table 4.0 discloses the overall results for serum lipids in $F$. catus. For TC, significant differences $(P<0.05)$ between the control group (SD) and CD, CA and CAA groups were detected at day 15, 30 and 45 . At the end of the experimental period, CD group gave the highest TC levels compared to others. Meanwhile, the CAA group displayed the lowest TC level. Comparing to the control group (SD) at day 45, the increase of TC levels in CD group was by 94\% while the TC levels in Spirulina supplemented groups have reduced by $60 \%$ (CA group) and $64 \%$ (CAA group).

In regard to $L D L$ levels, there was a drastic increase recorded at day 30 in CD group of which the level hit up from $24.37 \pm 3.58$ to $71.87 \pm 2.58 \mathrm{mg} \cdot \mathrm{dL}^{-1}$. The level was gradually increased at day 45 with $111.60 \pm 9.73 \mathrm{mg} \cdot \mathrm{dL}^{-1}$ $(P<0.05)$ that representing the highest LDL levels in this experiment. Almost the same scenario was also observed in TG levels. The cholesterol intake has forced the CD group to attain the highest TG levels at day 30 with $190.97 \pm 2.64 \mathrm{mg} \cdot \mathrm{dL}^{-1}(\mathrm{P}<0.05)$. The LDL and TG levels for both treated groups (CA and CAA) were slightly similar to the control group (SD). 
Table 3.0: Values of blood urea nitrogen (BUN) and creatinine $(\mathrm{Cr})$ in the cats on day $0,15,30$ and 45 of experimental period.

\begin{tabular}{|c|c|c|c|c|}
\hline Kidney's enzymes $\left(\mathrm{mg} \cdot \mathrm{dL}^{-1}\right) /$ Treatment group & Day 0 & Time (Day) Day 15 & Day 30 & Day 45 \\
\hline \multicolumn{5}{|l|}{ BUN } \\
\hline SD & $58.27 \pm 2.18^{a}$ & $65.33 \pm 3.78^{a}$ & $53.73 \pm 3.16^{\mathrm{ab}}$ & $44.33 \pm 2.22^{a}$ \\
\hline CD & $62.73 \pm 2.49^{\mathrm{a}}$ & $57.33 \pm 5.56^{\mathrm{a}}$ & $65.53 \pm 5.02^{b}$ & $52.67 \pm 4.22^{a}$ \\
\hline $\mathrm{CA}$ & $64.00 \pm 2.00^{\mathrm{a}}$ & $64.00 \pm 4.67^{\mathrm{a}}$ & $56.87 \pm 6.09^{b}$ & $43.00 \pm 3.33^{a}$ \\
\hline CAA & $62.33 \pm 3.11^{\mathrm{a}}$ & $64.83 \pm 1.22^{\mathrm{a}}$ & $39.00 \pm 1.33^{a}$ & $44.67 \pm 7.56^{\mathrm{a}}$ \\
\hline \multicolumn{5}{|l|}{ Creatinine } \\
\hline SD & $1.60 \pm 0.13^{a}$ & $1.67 \pm 0.04^{b}$ & $1.83 \pm 0.44^{\mathrm{bc}}$ & $1.8 \pm 0.07^{a}$ \\
\hline CD & $1.70 \pm 0.07^{\mathrm{a}}$ & $1.60 \pm 0.07^{b}$ & $1.47 \pm 0.04^{\mathrm{a}}$ & $1.83 \pm 0.04^{\mathrm{a}}$ \\
\hline $\mathrm{CA}$ & $1.70 \pm 0.07^{a}$ & $1.13 \pm 0.04^{\mathrm{a}}$ & $1.60 \pm 0.07^{a b}$ & $1.83 \pm 0.04^{a}$ \\
\hline CAA & $1.60 \pm 0.07^{a}$ & $1.80 \pm 0.07^{b}$ & $1.93 \pm 0.11^{c}$ & $2.13 \pm 0.04^{b}$ \\
\hline
\end{tabular}

*Values (mean \pm SD) with different superscripts in the same column were significantly different at the $5 \%$ level.

Table 4.0: Values of total cholesterol (TC), low density lipoprotein (LDL), triglyceride (TG) and high-density lipoprotein (HDL) in the cats throughout the experimental period.

\begin{tabular}{|c|c|c|c|c|}
\hline Concentration of serum lipids $\left(\mathrm{mg} \cdot \mathrm{dL}^{-1}\right) /$ Treatment group & 0 & Time (Day) 15 & 30 & 45 \\
\hline \multicolumn{5}{|l|}{ Total cholesterol (TC) } \\
\hline SD & $153.93 \pm 0.76^{a}$ & $150.20 \pm 2.27^{a}$ & $164.07 \pm 2.76^{\mathrm{a}}$ & $150.03 \pm 6.04^{\mathrm{a}}$ \\
\hline CD & $153.73 \pm 2.31^{\mathrm{a}}$ & $188.37 \pm 1.82^{\mathrm{b}}$ & $271.33 \pm 1.56^{b}$ & $291.67 \pm 2.87^{b}$ \\
\hline $\mathrm{CA}$ & $149.33 \pm 4.22^{\mathrm{a}}$ & $91.37 \pm 1.58^{c}$ & $63.57 \pm 1.71^{\mathrm{c}}$ & $59.43 \pm 3.91^{c}$ \\
\hline CAA & $144.67 \pm 2.44^{\mathrm{a}}$ & $86.17 \pm 2.11^{\mathrm{c}}$ & $48.90 \pm 4.60^{d}$ & $53.63 \pm 3.76^{c}$ \\
\hline \multicolumn{5}{|l|}{ Low density lipoprotein (LDL) } \\
\hline SD & $15.20 \pm 0.80^{a}$ & $39.93 \pm 1.91^{\mathrm{a}}$ & $20.40 \pm 3.60^{a}$ & $28.70 \pm 6.27^{a}$ \\
\hline CD & $15.60 \pm 1.73^{a}$ & $24.37 \pm 3.58^{b}$ & $71.87 \pm 2.58^{b}$ & $111.60 \pm 9.73^{b}$ \\
\hline $\mathrm{CA}$ & $22.57 \pm 2.38^{\mathrm{b}}$ & $22.40 \pm 3.07^{b}$ & $18.53 \pm 3.69^{a}$ & $44.3 \pm 5.13^{\mathrm{a}}$ \\
\hline CAA & $16.13 \pm 2.09^{\mathrm{ab}}$ & $24.50 \pm 4.33^{b}$ & $22.30 \pm 2.87^{\mathrm{a}}$ & $35.60 \pm 4.40^{\mathrm{a}}$ \\
\hline \multicolumn{5}{|l|}{ Triglyceride (TG) } \\
\hline SD & $41.60 \pm 2.13^{a}$ & $64.90 \pm 4.60^{\mathrm{a}}$ & $52.27 \pm 5.51^{\mathrm{a}}$ & $62.33 \pm 8.89^{a}$ \\
\hline CD & $62.57 \pm 2.38^{c}$ & $72.37 \pm 4.24^{\mathrm{a}}$ & $190.97 \pm 2.64^{b}$ & $146.33 \pm 10.44^{b}$ \\
\hline $\mathrm{CA}$ & $42.53 \pm 2.36^{a}$ & $60.30 \pm 3.53^{a}$ & $62.53 \pm 3.38^{a}$ & $67.33 \pm 3.56^{a}$ \\
\hline CAA & $51.70 \pm 2.20^{b}$ & $60.83 \pm 5.22^{\mathrm{a}}$ & $64.60 \pm 5.73^{a}$ & $65.40 \pm 6.93^{a}$ \\
\hline \multicolumn{5}{|l|}{ High density lipoprotein (HDL) } \\
\hline SD & $43.80 \pm 1.87^{\mathrm{a}}$ & $45.27 \pm 4.84^{\mathrm{a}}$ & $43.40 \pm 6.93^{\mathrm{ab}}$ & $38.37 \pm 6.911^{\mathrm{ab}}$ \\
\hline CD & $46.67 \pm 1.78^{a}$ & $37.10 \pm 5.40^{\mathrm{a}}$ & $28.53 \pm 6.36^{a}$ & $25.60 \pm 4.40^{\mathrm{a}}$ \\
\hline CA & $46.67 \pm 2.89^{a}$ & $47.73 \pm 5.82^{\mathrm{a}}$ & $72.87 \pm 6.08^{c}$ & $61.63 \pm 3.76^{c}$ \\
\hline CAA & $41.20 \pm 1.47^{\mathrm{a}}$ & $44.22 \pm 4.22^{\mathrm{a}}$ & $60.67 \pm 5.56^{b c}$ & $57.67 \pm 7.78^{\mathrm{bc}}$ \\
\hline
\end{tabular}

${ }^{*}$ Values (mean \pm SD) with different superscripts in the same column were significantly different at the $5 \%$ level.

Table 5.0: Effect of $S$. platensis on weight performance, serum lipids and kidney in different animal models supplemented with S. platensis.

\begin{tabular}{|c|c|c|c|c|}
\hline Animal & $\begin{array}{l}\text { Dose of } S . \\
\text { platensis }\end{array}$ & Duration & $\begin{array}{l}\text { Effect of } S \text {. platensis on weight performance, serum lipids and } \\
\text { kidney }\end{array}$ & References \\
\hline Lambs & $\begin{array}{l}1 \mathrm{~g} / 10 \mathrm{~kg} \text { body } \\
\text { weightday }\end{array}$ & 35 days & $\begin{array}{l}\text { Weights increased } 9.7 \% \text { higher than control group } \\
\text { TG and TC levels were significantly reduced at day } 17(\mathrm{P}<0.05) \\
\text { HDL levels were not reported } \\
\text { Urea was not significantly changed at day } 35\end{array}$ & $\begin{array}{l}\text { El-Sabagh et al., } \\
2014\end{array}$ \\
\hline Rabbits & $0.5 \mathrm{~g} / \mathrm{day}$ & 60 days & $\begin{array}{l}\text { Weights increased } 3.6 \% \text { higher than control group } \\
\text { Only TC levels denoted significant decreases }(P<0.05) \\
\text { HDL levels showed significant increases with } P<0.05 \\
\text { Kidney status was not reported }\end{array}$ & Colla et al., 2008 \\
\hline Rats & $48.03 \mathrm{~g} / 100 \mathrm{~g}$ & 10 days & $\begin{array}{l}8.5 \% \text { body weight increase recorded } \\
\text { TC and LDL+VLDL levels were significantly decreased }(P<0.05) \\
\text { HDL levels were significantly increased }(P<0.05) \\
\text { Kidney status was not reported }\end{array}$ & $\begin{array}{l}\text { Nagaoka et al., } \\
2005\end{array}$ \\
\hline Calves & 25 g/day & 57 days & $\begin{array}{l}104 \% \text { weights gain higher than control group } \\
\text { TC and LDL levels were significantly decreased }(P<0.05) \\
\text { HDL levels induced }(P<0.05) \\
\text { BUN levels slightly similar to the control levels }\end{array}$ & $\begin{array}{l}\text { Heidarpour et al., } \\
2011\end{array}$ \\
\hline
\end{tabular}


Both single and double doses of $S$. platensis LUQS1 (CA and CAA groups) demonstrated the better enhancement in HDL levels compared to SD and CD groups. The highest level for HDL was recorded at day 30 in the CA group with about $68 \%$ higher than the SD group. A comparison of the effect of $S$. platensis on different animals was summarized in Table 5.0. Based on the results, $S$. platensis provided several beneficial advantages on animals mostly in their weight performance and also serum lipids elevation. Besides, the kidney of a few of the tested animals remained healthy and unaffected. The pre-clinical tests have proven that the positive effects of this cyanobacterium occur at an extensive range of animals' species.

The animals employed in this study were adult and healthy domestic cats. Their diets were mixed with cholesterol in order to achieve a hyperlipidemic condition. Atherosclerosis is one of the hyperlipidemic events which could occur in human and animal. However, cats, rats, mice, pigs, cows, horses and dogs are among animals with atherosclerosis resistance owing to their low CETP level (Guyard-Dangremont et al., 1998). CETP is responsible to assist the transport of cholesterol and triglycerides between the lipoproteins. Lacking in CETP resulted in more cholesterol to be transported as HDL. Report by Manning and Clarkson (1970) was not proportional to the statement as there was atherosclerosis event detected in cats. Based on their study, atherosclerosis has successfully developed in the abdominal aorta and coronary artery. They have induced the serum cholesterol levels using a diet rich in lard at concentrations of $0.5 \%$ (for 8 months) and $2 \%$ (for 4 months). Thus, understanding the basic lipoprotein metabolism is imperative since many diseases could amend this process due to the elevation levels in plasma lipid (Johnson, 2005). In this experiment, the application of higher cholesterol percentage specifically ( $9 \%$ cholesterol per body weight) has effectively elevated the serum lipids in domestic $F$. catus after 45 days of the study period. These outcomes were aligned with Ginzinger et al. (1997) where the application of $30 \%$ fat and $3 \%$ cholesterol showed significant changes in serum lipids, providing the basis evaluation for susceptibility of New Zealand lipoprotein lipase-deficient cats to diet-induced atherosclerosis (Ginzinger et al., 1999).

Previous studies have reported the valuable therapeutic functions of Spirulina sp. as anti-cholesterol, anti-inflammatory, anti-pyretic, antibacterial and anticancer agent (Ozdemir et al., 2004; Kim and Kim, 2005; El-Sabagh et al., 2014; Konícková et al., 2014 Muhammad Nazrul et al., 2014). Referring to Deng and Chow (2010), any agents with antioxidant and antiinflammatory activities own a tremendous potential for combating CVDs. Commonly, antioxidant properties could lessen the oxidation of lipids and proteins that indirectly defend the body from arterial stiffening and atherosclerosis (Carty et al., 2000; Carpenter et al., 2003; Ellingsen et al., 2009). In Spirulina sp., phycocyanin, $\beta$ carotene and $y$-linolenic acid are among super antioxidants which have been recognized affecting the
CDVs by numbers of researchers (Nagaoka et al., 2005; Colla et al., 2008; Deng and Chow, 2010). Scavenging free radicals, reducing nitrite production and inhibiting liver microsomal lipid peroxidation are among phycocyanin's abilities (Remirez et al., 2002; Romay et al., 2003; Khan et al., 2006; Cherng et al., 2007; Riss et al., 2007). $\beta$ carotene involves in lipid peroxidation (Schafer et al., 2002) while $y$-linolenic acid, a precursor to body's prostaglandin, engages with cholesterol synthesis (Krone et al., 1988).

A few accessible reports regarding cats were commonly on renal failure (Deguchi and Akuzawa, 1997), hypertension (Chetboul et al., 2003), obesity (German, 2006) and lipid-related study (Ginzinger et al., 1999; Datz et al., 2009). Based on this recent data, a tremendous potential in treating lipid-related events in $F$. catus using natural cyanobacterium was discovered. It can be a new promising and cheaper source to be supplemented in the cats' daily diets.

\section{CONCLUSION}

Studies assessing the efficacy of Spirulina sp. and clinical practice in $F$. catus are constrained. In this experiment, $S$. platensis LUQS1 (CA and CAA groups) has effectively reduced the TC, TG and LDL levels in cats-fed high cholesterol which simultaneously induced the HDL levels without affecting the kidney condition. Thus, this cyanobacterium has proven its anti-hyperlipidemic function as previously reported by researchers in this study herein.

\section{ACKNOWLEDGEMENT}

The authors would like to thank Ministry of Education Malaysia (MOE) for the grant awarded and also all the staffs at Faculty of Veterinary Medicine, Universiti Malaysia Kelantan for their guidance.

\section{REFERENCES}

AOAC. (1997). Official methods of analysis of AOAC International (16th edn). In: Official method of analysis, Cunniff, P.A. (eds.). Virginia AOAC International, Arlington, VA. pp. 11-116.

Azabji-Kenfack, M., Edie Dikosso, S., Loni, E. G., Onana, E. A., Sobngwi, E., Gbaguidi, E., Ngougni Kana, A. L., Nguefack-Tsague, G., Von der Weid, D., Njoya, O. and Ngogang, J. (2011). Potential of Spirulina platensis as a nutritional supplement in malnourished HIV-infected adults in sub-saharan Africa: A randomised, single-blind study. Nutrition and Metabolic Insights 4, 29-37.

Carpenter, K. L., Kirkpatrick, P. J., Weissberg, P. L., Challis, I. R., Dennis, I. F., Freeman, M. A. and Mitchinson, M. J. (2003). Oral alpha-tocopherol supplementation inhibits lipid oxidation in established human atherosclerotic lesions. Free Radical Research 37, 1235-1244. 
Carty, J. L., Bevan, R., Waller, H., Mistry, N., Cooke, M., Lunec, J. and Griffiths, H. R. (2000). The effects of vitamin $\mathrm{C}$ supplementation on protein oxidation in healthy volunteers. Biochemical and Biophysical Research Communications 273, 729-735.

Cheong, S. H., Kim, M. Y., Sok, D. E., Hwang, S. Y., Kim, J. H., Kim, H. R., Lee, J. H., Kim, Y. B. and Kim, M. R. (2010). Spirulina prevents atherosclerosis by reducing hypercholesterolemia in rabbits fed a highcholesterol diet. Journal of Nutritional Science and Vitaminology 56(1), 34-40.

Cherng, S. C., Cheng, S. N., Tarn, A. and Chou, T. (2007). C. Anti-inflammatory activity of c-phycocyanin in lipopolysaccharide-stimulated RAW 264.7 macrophages. Life Sciences 81, 1431-1435.

Chetboul, V., Lefebvre, H. P., Pinhas, C., Clerc, B., Boussouf, M. and Pouchelon, J. L. (2003). Spontaneous feline hypertension: Clinical and echocardiographic abnormalities, and survival rate. Journal of Veterinary Internal Medicine 17, 89-95.

Colla, L. M., Muccillo-Baisch, L. and Costa, J. A. V. (2008). Spirulina platensis effects on the levels of total cholesterol, HDL and triacylglycerols in rabbits fed with a hypercholesterolemic diet. Brazilian Archives of Biology and Technology 51(2), 405-411.

Datz, C. A., Backus, R. C. and Fritsche, K. L. (2009). Dietary diacylglycerol oil has no effect on hypertriacylglycerolaemia in lipoprotein lipase-deficient cats. British Journal of Nutrition 102, 1024-1029.

Deguchi, E. and Akuzawa, M. (1997). Renal clearance of endogenous creatinine, urea, sodium, and potassium in normal cats and cats with chronic renal failure. The Journal of Veterinary Medical Science 59(7), 509-12.

Deng, P. and Swanson, K. S. (2015). Gut microbiota of humans, dogs and cats: Current knowledge and future opportunities and challenges. British Journal of Nutrition 113 Suppl., S6-17.

Deng, R. and Chow, T. J. (2010). Hypolipidemic, antioxidant and anti-inflammatory activities of microalgae Spirulina. Cardiovascular Therapeutics 28(4), e33-e45.

Devi, M. A. and Venkataraman, L. V. (1983). Hypocholestemic effect of bluegreen algae Spirulina platensis in albino rats. Nutrition Reports International 28, 519-530.

Ellingsen, I., Seljeflot, I., Arnesen, H. and Tonstad, S. (2009). Vitamin $C$ consumption is associated with less progression in carotid intima media thickness in elderly men: A 3-year intervention study. Nutrition, Metabolism and Cardiovascular Diseases 19, 8-14.

El-Sabagh, M. R., Eldaim, M. A. A., Mahboub, D. H. and Abdel-Daim, M. (2014). Effects of Spirulina platensis algae on growth performance, antioxidative status and blood metabolites in fattening lambs. Journal of Agricultural Sciences 6(3), 92-96.

German, A. J. (2006). The growing problem of obesity in dogs and cats. Journal of Nutrition 136(7), 1940S1946 S.
Gershwin, M. E and Belay, A. (2008). Spirulina in human nutrition and health. CRC Press, Taylor and Francis Group, Boca Raton, London, NY. pp. 1-25.

Ginzinger, D. G., Clee, S. M., Dallongeville, J., Lewis, M. E., Henderson, H. E., Bauje, E., Rogers, Q. R., Jensen, D. R., Eckel, R. H., Dyer, R., Innis, S., Jones, B., Fruchart, J. C. and Hayden, M. R. (1999). Lipid and lipoprotein analysis of cats with lipoprotein lipase deficiency. European Journal of Clinical Investigation 29(1), 17-26.

Guyard-Dangremont, V., Desrumaux, C., Gambert, P., Lallemant, C. and Lagrost, L. (1998). Phospholipid and cholesteryl ester transfer activities in plasma from 14 vertebrate species. Relation to atherogenesis susceptibility. Comparative Biochemistry and Physiology Part B: Biochemistry and Molecular Biology 120(3), 517-525.

Heidarpour, A., Fourouzandeh-Shahraki, A. D. and Eghbalsaied, S. (2011). Effects of Spirulina platensis on performance, digestibility and serum biochemical parameters of Holstein calves. African Journal of Agricultural Research 6(22), 5061-5065.

Johnson, M. C. (2005). Hyperlipidemia disorders in dogs. Compendium Continuing Education for Veterinarians 27(5), 361-370.

Kenneth, S. L. (2011). Duncan and Prasse's Veterinary Laboratory Medicine: Clinical Pathology. ( $5^{\text {th }}$ ed). John Wiley \& Sons Inc., Oxford, UK. pp. 1-524.

Khan, M., Varadharaj, S., Shobha, J. C., Naidu, M. U., Parinandi, N. L., Kutala, V. K. and Kuppusamy, P. (2006). C-phycocyanin ameliorates doxorubicininduced oxidative stress and apoptosis in adult rat cardiomyocytes. Journal of Cardiovascular Pharmacology 47, 9-20.

Kim, M. H. and Kim, W. Y. (2005). The change of lipid metabolism and immune function caused by antioxidant material in hypercholesterolemin elderly women in Korea. Korean Journal of Nutrition 38, 6775.

Kline, K. L. (2005). Neurologic manifestations of systemic disease. in: textbook of veterinary internal medicine. Ettinger, S. J. and Feldman, E. C. (eds.). Saunders, Philadelphia. pp. 153.

Kluger, E.K., Hardman, C., Govndir, M., Baral, R. M., Sullivan, D.R., Snow, D. and Malik, R. (2009). Triglyceride response following an oral fat tolerance test in Burmese cats, other pedigree cats and domestic crossbred cats. Journal of Feline Medicine and Surgery 11, 82-90.

Konícková, R., Vanková, K., Vaníková, J., Vánová, K., Muchová, L., Subhanová, I., Zadinová, M., Zelenka, J., Dvorák, A., Kolár, M., Strnad,H., Rimpelová, S., Ruml, T., Wong, R. J. and Vítek, L. (2014). Anticancer effects of blue-green alga Spirulina platensis, a natural source of bilirubin-like tetrapyrrolic compounds. Annals of Hepatology 13(2), 273-283.

Krone, W., Klass, A., Nägele, H., Behnke, B. and Greten, H. (1988). Effects of prostaglandins on LDL receptor activity and cholesterol synthesis in 
freshly isolated human mononuclear leukocytes. The Journal of Lipid Research 29(12), 1663-1669.

Manning, P. J. and Clarkson, T. B. (1970). Diet-induced atherosclerosis of the cat. Hyperlipidemia disorders in dogs. Archives of Pathology and Laboratory Medicine 89(3), 271-278.

Mosallanejad, B., Avizeh, R., Jalali, R. and Pourmahdi, M. (2016). Comparative evaluation between chitosan and atorvastatin on serum lipid profile changes in hyperlipidemic cats. Iranian Journal of Veterinary Research 17(1), 36-40.

Muhammad Nazrul, S., Nor Azura, M., Zuraini, A., Zainul Amiruddin, Z., Lokman, S., Mohd Sofian, 0. F. and Arifah, A. K. (2014). Anti-inflammatory and anti-pyretic properties of Spirulina platensis and Spirulina lonar: A comparative study. Pakistan Journal of Pharmaceutical Sciences 27(5), 1277-1280.

Nagaoka, S., Shimizu, K., Kaneko, H., Shibayama, F., Morikawa, K., Kanamaru, Y., Otsuka, A., Hirahashi,T. and Kato, T. (2005). A novel protein Cphycocyanin plays a crucial role in the hypocholesterolemic action of Spirulina platensis concentrate in rats. Journal of Nutrition 135(10), 24252430.

Nakaya, N., Honma, Y. and Goto, Y. (1988). Cholesterol lowering effect of Spirulina. Nutrition Reports International 37, 1329-1337.

Ozdemir, G., Karabay, N. U., Dalay, M. C. and Pazarbasi, B. (2004). Antibacterial activity of volatile component and various extracts of Spirulina platensis. Phytotherapy Research 18(9), 754-757.

Remillard, R. L. (2005). Obesity. In: Textbook of Veterinary Internal Medicine. Ettinger, S. J. and Feldman, E.C. (eds.). Saunders, Philadelphia. pp. 76.

Remirez, D., Fernández, V., Tapia, G., González, R. and Videla, L. A. (2002). Influence of C-phycocyanin on hepatocellular parameters related to liver oxidative stress and Kupffer cell functioning. Inflammation Research 51, 351-356.

Riss, J., Décordé, K., Sutra, T., Delage, M., Baccou, J. C., Jouy, N., Brune, J. P., Oréal, H., Cristol, J. P. and Rouanet, J. M. (2007). Phycobiliprotein Cphycocyanin from Spirulina platensis is powerfully responsible for reducing oxidative stress and NADPH oxidase expression induced by an atherogenic diet in hamsters. Journal of Agricultural and Food Chemistry 55, 7962-796.

Romay, Ch., González, R., Ledón, N., Remirez, D. and Rimbau, V. (2003). C-phycocyanin: A biliprotein with antioxidant, anti-inflammatory and neuroprotective effects. Current Protein and Peptide Science 4, 207216.

Saeid, A., Chojnacka, K., Korczyński, M., Korniewicz, D. and Dobrzański, Z. (2013). Effect on supplementation of Spirulina maxima enriched with $\mathrm{Cu}$ on production performance, metabolical and physiological parameters in fattening pigs. Journal of Applied Phycology 25(5), 1607-1617.

Schafer, F. Q., Wang, H. P., Kelley, E. E., Cueno, K. L., Martin, S. M. and Buettner, G. R. (2002). Comparing beta-carotene, vitamin $\mathrm{E}$ and nitric oxide as membrane antioxidants. Journal of Biology Chemistry 383, 671681.

Steiner, J. M. and Williams, D. A. (2005). Feline exocrine pancreatic disease. In: Textbook of Veterinary Internal Medicine. Ettinger, S. J. and Feldman, E.C. (eds.). Saunders, Philadelphia. pp. 1489.

Tovar-Ramírez, D., Zambonino, J., Cahu, C., Gatesoupe, F. J., Vázquez, J. R. and Lésel, R. (2002). Effect of live yeast incorporation in compound diet on digestive enzyme activity in sea bass (Dicentrarchus labrax) larvae. Aquaculture 204, 113123.

Tucci-Prosěk, T. R. (2005). Acute vision loss in small animals. In: Textbook of Veterinary Internal Medicine. Ettinger, S. J. and Feldman, E.C. (eds.). Saunders, Philadelphia. pp. 96.

Xenoulis, P.G. and Steiner, J. M. (2010). Lipid metabolism and hyperlipidemia in dogs. Veterinary Journal 183, 12-21.

Xiangdong, L., Yuanwu, L., Hua, Z., Liming, R., Qiuyan, L. and Ning, L. (2011). Animal models for the artgerosclerosis research: A review. Protein and Cell 2(3), 189-201.

Zarrouk, C. (1966). Influence de divers facteurs physiques et chimiques sur la croissance et photosynthese de Spirulina maxima Geitler. Ph.D. Thesis. University of Paris, France. 